\title{
Hidden in plain sight: detectability and habitat selection of the central plateau dusky rattlesnake in anthropized landscapes
}

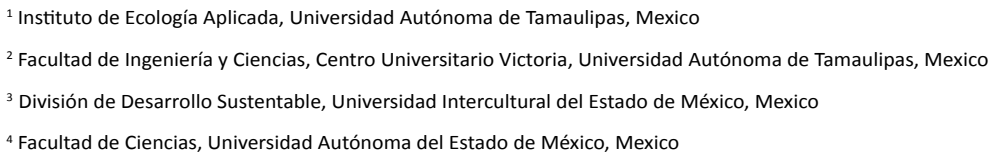

Leroy Soria-Díaz ${ }^{1}$, Claudia C. Astudillo-Sánchez², Yuriana Gómez-Ortiz² ${ }^{3}$ Javier Manjarrez4, Víctor Mundo-Hernández ${ }^{4}$, Tamara Rubio-Blanco ${ }^{3}$ \& Hublester Domínguez-Vega ${ }^{3}$

Human activities have caused several changes in biotic communities all over the world. Some species maintain viable populations in altered environments through different adaptations, however, knowledge in this regard is scarce for certain taxa, including reptiles. We analysed the detectability and habitat selection of the rattlesnake Crotalus triseriatus to contribute to our knowledge about how this species responds to anthropogenic landscape change. Rattlesnakes were monitored for two years in two anthropized landscapes using visual encounter surveys. We analysed detectability in relation to climatic factors and human activity, and habitat selection was analysed in native and non-native vegetation. Our study shows that detectability of $C$. triseriatus is differentially affected in anthropized landscapes; human activity may be determinant in landscapes such as agricultural fields, whilst climatic factors may be determinant in landscapes where people are less active such as the protected areas within urban parks. The analyses of habitat selection shows that native vegetation is crucial for the persistence of $C$. triseriatus in the studied landscapes. Several strategies may allow rattlesnakes to persist in different anthropized landscapes; nonetheless, native habitat remnants should be protected in anthropized areas to conserve wildlife.

Keywords: Anthropized landscapes, behavioural adaptations, Mexico, native habitat remnants, urban herpetology

\section{INTRODUCTION}

In urban areas, human activities have changed the structure and composition of biotic communities and natural ecosystem processes (McDonnell \& Hahs, 2015). Some species maintain viable populations in these areas due to their adaptive capacity (McDonnell \& Hahs, 2015; Pattishall \& Cundall, 2009; Wong \& Candolin, 2015). The effect of anthropization on wildlife behaviour has been documented mainly in mammals and birds (Gloor et al., 2001; Marzluff \& Ewing, 2001; Prange et al., 2003), whilst relatively few studies have focused on reptiles (Mitchell et al., 2008). Knowledge is particularly scarce in snakes due to their relatively low density and secretive behaviour (Sullivan et al., 2017).

Behavioural adaptations stand out among the different strategies (i.e. evolved responses and proximate responses) that favour the persistence of reptiles in modified environments (e.g. activity pattern, habitat selection, and diet; López-Alcaide \& Macip-Ríos, 2011). Such strategies have been directly related to survival and reproduction (Beaupre, 1995; Manjarrez, 2017; TorelloViera et al., 2012). Otherwise, some abiotic factors such as temperatures and rainfall play a key role in snake detectability, activity patterns and habitat selection (Lillywhite, 1987; Moreno-Rueda \& Pleguezuelos, 2007). For example, in temperate zones, snakes overwinter when temperature decrease (Gregory, 1982), and in many ecosystems, an increase in rainfall is related to higher seasonal detectability due to the increased availability of prey (Torello-Viera et al., 2012). Moreover, some snakes show high plasticity in the habitat use that could be determined by factors such as the intensity of human activities, the availability of prey, presence of optimal thermoregulation sites (Huey et al., 1989; Madsen \& Shine, 1996), and/or adequate shelter (Brown et al., 1982).

The western dusky rattlesnake, Crotalus triseriatus, is endemic to Central Mexico along the Volcanic Belt (Bryson et al., 2014; Flores-Villela \& Hernández-García, 1989). Its elevational distribution is from 2,500 to 4,572 m above mean sea level (m/a.s.l.) (Campbell \& Lamar, 2004; Fernández-Badillo et al., 2011; Heimes, 2016). This species has a daytime activity pattern and is mainly found in pine-oak forests, grasslands, and agricultural areas such as cattle pasture (Canseco-Márquez \& MendozaQuijano, 2007; Fernández-Badillo et al., 2011). It is a common predator of temperate environments in central 
Mexico where it may be considered a top predator in anthropogenic areas. Like other snakes, it is affected by aversive hunting, native habitat loss, fragmentation, and climate change (Campbell \& Lamar, 2004; Filippi \& Luiselli, 2000; Gentilli, 2004; Plummer, 2002).

Ecological studies of $C$. triseriatus are scarce (Domínguez-Guerrero et al., 2016; Güizado-Rodríguez et al., 2016; Mociño-Deloya et al., 2014), but it has been suggested that the vulnerability of $C$. triseriatus populations when faced with fragmentation and habitat urbanisation may result in a decrease of gene flow and increased extinction risk (Sunny et al., 2015). It is, therefore, necessary to collect information on the behaviour and habitat preference of $C$. triseriatus to inform conservation efforts. The objective of this study was to analyse the detectability and habitat selection of $C$. triseriatus to identify the factors that allow its occurrence in anthropized areas of central Mexico.

\section{METHODS}

\section{Study area}

This study was conducted in the Toluca Valley, a highly anthropized area considered the fifth largest metropolis in Mexico, with 2.3 million inhabitants (COESPO, 2020). The region has a humid temperate climate with an annual rainfall of $500-600 \mathrm{~mm}, 85 \%$ is concentrated in the summer months (June to September). Average annual temperature ranges between 12 and $15^{\circ} \mathrm{C}$ (García, 2004; INEGI, 2011). Toluca has experienced rapid population growth with the consequent settlement of unplanned housing and increased demand for agricultural areas. Human activities have drastically changed the distribution of native vegetation cover, generating several landscapes around the urban core. As in many cities, the most common anthropized landscapes in the urban area of Toluca include relicts of native vegetation, agricultural areas, reforested areas with exotic vegetation, and urban infrastructure.

Our study was conducted at two different landscapes in the urban area of Toluca separated by a straightline distance of $10.5 \mathrm{~km}$. We selected the study sites considering that both sites presented previous records of the rattlesnake, both include elements of the native habitat of Crotalus triseriatus and the non-native elements of the most common landscapes around the Urban area of Toluca (i.e. agricultural areas, reforested areas with exotic vegetation). Anthropization at these sites has been determined by different activities, thus leading to landscapes with noticeable differences in structure, composition, and management.

Site one, "El Cerrillo" (CE), is an academic area managed by the Autonomous University of the State of Mexico. This area covers approximately 123 hectares and is located $5.1 \mathrm{~km}$ north of the urban area of Toluca City $\left(19^{\circ} 24^{\prime} 27^{\prime \prime} \mathrm{N}, 99^{\circ} 41^{\prime} 40^{\prime \prime} \mathrm{W}\right)$. This site may be considered a typical agricultural landscape (i.e. most of the area is covered by crops) and has been under this use since 1975 (45 years). CE also includes two artificial water bodies, one of them is a small protected area of flora and fauna. The native vegetation consists of grassland (Muhlenbergia sp. and Festuca sp.) and aquatic vegetation (Scirpus sp. and Typha latifolia). The non-native vegetation consists of crop fields and some trees (Salix babylonica). Site two, "Sierra Morelos Park" (SMP), is an urban state park of 1,255 hectares managed by the state commission of natural parks and fauna (CEPANAF) since 1976 (44 years); it is immersed in the urban area of Toluca City (19²18'39" N 99 $41^{\prime} 33^{\prime \prime}$ W; 2,630 $\mathrm{m})$. SMP vegetation is mainly represented by grasslands (Muhlenbergia sp. and Festuca sp.), and temperate forest vegetation (Pinus spp.); it also includes a substantial cover of non-native vegetation, mainly exotic species (buds, Buddleja cordata; cedar, Cupresus lindleyi; eucalyptus, Eucalyptus camaldulensis and E. globulus). To eliminate the effect of the size differences between CE and SMP, the sampling area was approximately 20 hectares in both places (Fig. 1).

\section{Detectability}

To determine the detectability of $C$. triseriatus, we performed monthly visits to each study site during 2012 and 2013 (24 visits to each one) and captured individuals of C. triseriatus. At each visit, five observers simultaneously walked five linear transects from 0900 to 1300 hours using the visual encounter survey (VES) technique (Foster, 2012). Each transect was approximately 800 $\mathrm{m}$ long and separated by 200 to $300 \mathrm{~m}$. Transects may change between visits, but they were always restricted to the 20 hectare area defined for each site, our aim in this regard was to cover all types of vegetation in a similar proportion to their presence. The snakes were manually captured, their snout-to-vent length (SVL) measured, and a ventral scale was cut to identify individuals (Brown \& Parker, 1976). Snakes were released in the same place from where they were captured. Additionally, we compared SVL between CE and SMP to test if body size varied between the two sites.

Detectability was determined by counting the number of adult $C$. triseriatus captured during each visit per study site. We recorded data only for adult individuals ( $S V L \geq 500 \mathrm{~mm}$ ) as immature snakes may have led to bias due to the recruitment process (Parpinelli \& Marques, 2008; Torello-Viera et al., 2012); as we aim to analyse detectability, we also considered recaptured individuals in this analysis (one individual). We analysed detectability of $C$. triseriatus (response variable) in relation to abiotic (total precipitation, maximum and minimum temperature), and biotic factors (human activity) using general linear models (GLMs) in $\mathrm{R}$ version 3.6.3 (R Core Team 2020). For the abiotic factors, we obtained monthly climate data of the climatic variables from the National Meteorological Service database (CLICOM, 2015) for the nearest weather station to CE (< $20 \mathrm{~km}$; weather station "Toluca-Ixtlahuaca", 19³3'58" $\mathrm{N}, 99^{\circ} 46^{\prime} 48^{\prime \prime} \mathrm{W}, 2,540 \mathrm{~m}$ ), and SMP (<3 km "TolucaZinacantepec", 19¹7'29" N, 9942'52" W; 2,726 m). We also considered the human activity as an important factor to explain snake detectability; for this variable, we characterised both sites based on human presence 

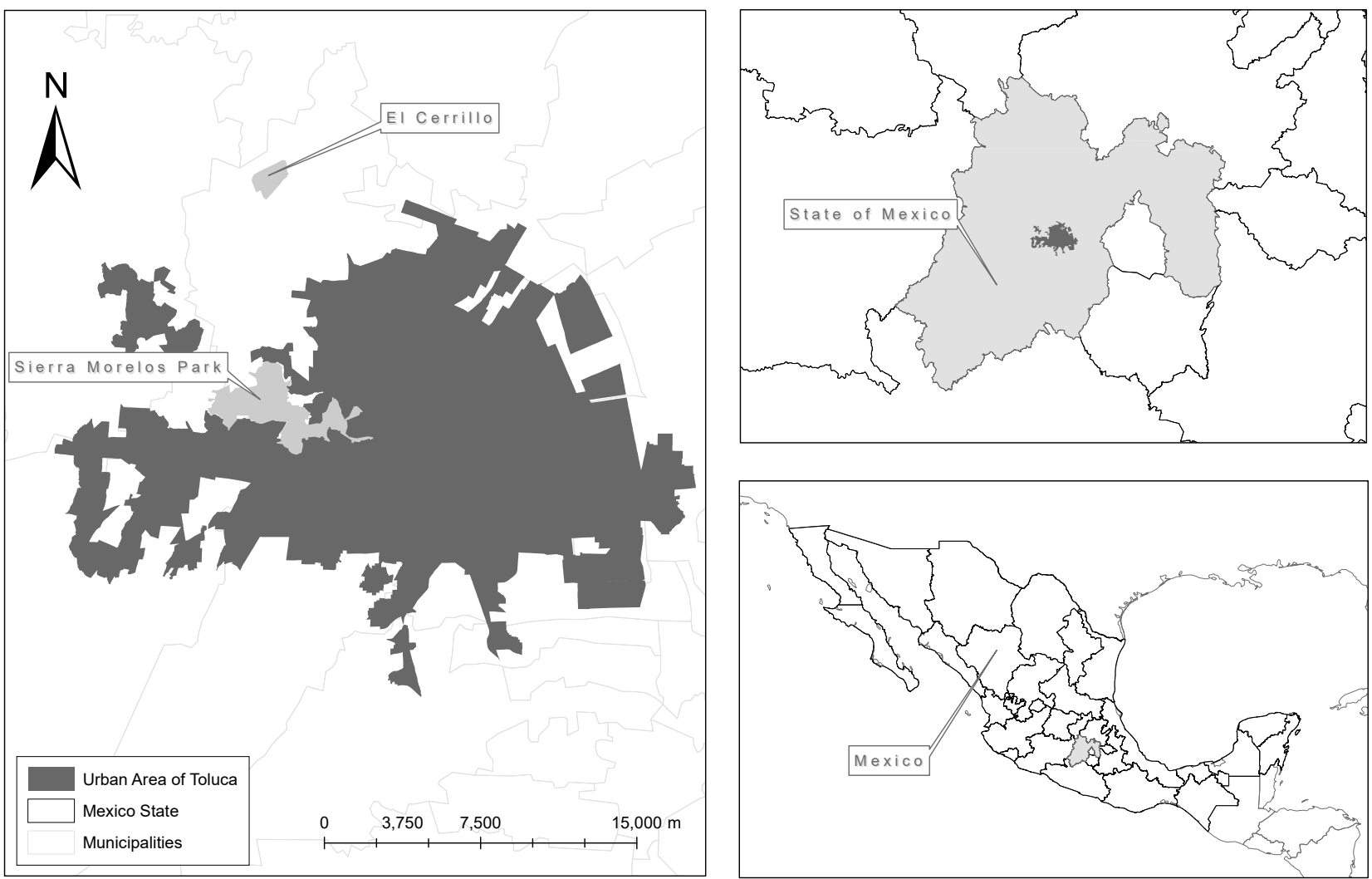

Figure 1. Distribution of the study sites in the urban area of Toluca City, Mexico.

through the year using direct observations at both sites. We codified human activity as absent (0), low human activity (1), and high human activity (2).

Detectability of $C$. triseriatus (number of snakes captured) was assumed to have a Poisson probability distribution and given that our data presented zero values, we used Zero-Inflated Poisson model as a solution for possible bias in the estimated parameters (Zuur et al., 2009), using the "pscl" package (Jackman, 2020). Multiple models were developed using plausible combinations of explanatory variables; small sample Akaike's information criterion (AICC) was used to select the "best" models of detectability of $C$. triseriatus in relation to explanatory variables, using the 'AICcmodavg' package (Burnham \& Anderson, 2002; Mazerolle, 2019). Finally, Chisquare tests were conducted to evaluate whether GLM explanatory variables explained a significant component of the total deviance (Guisan et al., 2002).

\section{Habitat selection}

We used satellite imagery (Google Earth) and ArcGIS 10.2 to digitise land cover in both study sites (approximately 20 hectares at each site), and calculated the area represented by native habitat and non-native habitat for each site. Native and non-native habitat cover is noticeably different between our study sites. At CE non-native vegetation represents $87.3 \%$ of the area including crops and exotic trees (S. babilonica). Crops are concentrated in four big patches separated by a road bordered with introduced trees. Native vegetation covers $12.7 \%$ of the area and is restricted in two small patches separated by the crops. At SMP native vegetation represents $58.4 \%$ of the area and is concentrated in a big patch of grassland and another one of forest, both are separated by a road. Non-native vegetation is dispersed in several small patches of exotic trees mostly next to the road.

We used the index of selectivity $\left(E_{i}\right)$ according to Krebs (1999): $E_{i}=\left(r_{i}-n_{i}\right) /\left(r_{i}+n_{i}\right)$, where $r_{i}$ is the percentage of snakes in habitat $i ; n_{i}$ is the percentage of habitat $i$ available at a study site. This index produces values from - 1 (habitat avoidance) to +1 (habitat preference); values close to zero indicate habitat is being used according to its availability in the environment. The index data were resampled using bootstrap $(10,000$ replicates with replacement) and $95 \%$ confidence intervals $(\mathrm{Cl})$ were estimated with R (v. 3.1.3; Glen et al., 2012).

\section{RESULTS}

During the monthly visits at each study site (CE and SMP), we sampled $192 \mathrm{~km}$ of transects and captured 61 different adult $C$. triseriatus; 23 (37.7 \%) were from CE, and $38(62.3 \%)$ from SMP. Snakes from CE were slightly larger $(605.6 \pm 75.5 \mathrm{~mm}, \mathrm{SVL})$ than SMP $(589.7 \pm 80.4$ $\mathrm{mm}$ ). Considering that measurements of the snakes from CE did not show a normal distribution (Shapiro-Wilk test; $\mathrm{W}=0.98 \mathrm{P}=0.95)$ and that those from SMP were normally distributed ( $W=0.91, P=0.007)$, we use a non-parametric Mann-Whitney U test (Zar, 1999) and we detected no significant difference in body size between the two sites $(\mathrm{U}=542.5, \mathrm{P}=0.11)$. 


\section{Detectability}

We captured rattlesnakes in all months except February and March at the Toluca valley. Most of the records (61\%), were gathered during the rainy season (June to September). At SMP, $68 \%$ of the snakes were recorded during the rainy season, whilst $48 \%$ were recorded in the same season at CE. Concerning detectability, at CE, we observed two peaks; August (summer) and November (autumn), both months with six snakes captured (Fig. 2A). In contrast, at SMP, snakes presented only one detectability peak in September (11 snakes captured, Fig. 2B). Most snakes were captured from 1000-1100 hours in both sites (CE, $56.5 \%$; SMP, $52.6 \%$ ) regardless of the month.
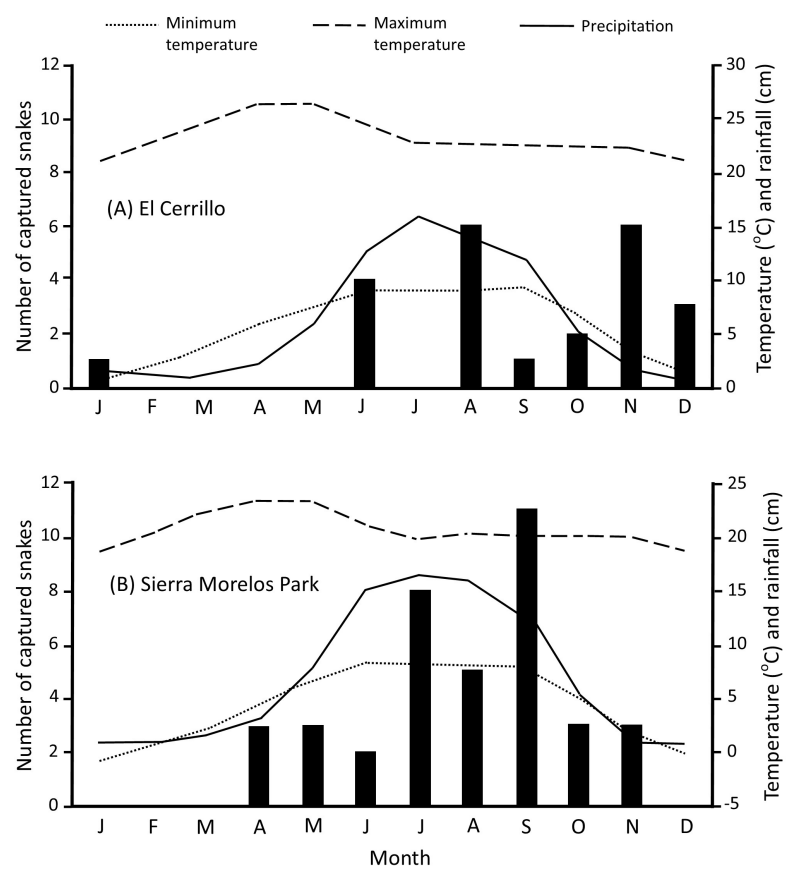

Figure 2. Monthly number of captured rattlesnakes, $C$. triseriatus (bars), monthly precipitation average and temperature (maximum and minimum) at: (A) El Cerrillo (CE; high anthropization; $n=23$ snakes), and (B) Sierra Morelos Park (SMP; low anthropization; $n=38$ snakes).

At CE, we observed two peaks of human activity, the first one from February to May, is related to soil preparing before sowing; the second one in September coincides with the harvest period. The rest of the year, the human presence was considered absent. Human activity at SMP is heterogeneous; there is an area where people use to practice sports and recreational activities through the year; at the other portion of the park, human activity is non-allowed because it is considered a conservation reserve for native fauna. Thus, activity was considered very low and homogeneous through the year in the area where we sampled, and we assumed that this factor does not affect (or is too low), the detectability of rattlesnakes. According to the evaluation of GLMs, and based on AIC values, we found that simple single variable models better explain the detectability of snakes at both sites. At CE human activity explained better the detectability of rattlesnakes (Table 1 ; $A I C_{c}=58.35$ ), in this case, the detectability of $C$. triseriatus decreases when human activity increased (slope estimate $=-2.75+1.03$; Table 2). This model was significant according to the Chi-square test (sum-of-squares method, type II; $X^{2}=7.06, d f=1$, $P=0.007)$. At SMP, based on AIC values, minimum temperature variable explained better the $C$. triseriatus detectability (Table $1 ; A_{c}=58.35$ ), this simple GLM model indicates that as the minimum temperature increased, the detectability of the snake also increases (slope estimate $=0.30+0.07$; Table 2 ) and this model was also significant (sum-of-squares method, type II; $X^{2}=17.40, d f=1, P=<0.001$ ).

Table 1. AIC selection of different zero-inflated Poisson general linear models (GLMs) of $C$. triseriatus detectability in two sites with different levels of anthropization in Mexico; "El Cerrillo" (CE) considered as highly anthropized and the Sierra Morelos Park (SMP) minimally anthropized.

\begin{tabular}{llll}
\hline $\begin{array}{l}\text { Models of } \text { C. triseriatus } \\
\text { detectability }\end{array}$ & K & AIC $_{\mathbf{c}}$ & AAIC $_{\mathbf{c}}$ \\
\hline El Cerrillo (CE) & 3 & 58.35 & 0.00 \\
H_Activ & 4 & 60.74 & 2.38 \\
H_Activ+TMin & 4 & 60.91 & 2.56 \\
H_Activ+Prec & 5 & 60.99 & 2.64 \\
H_ActivXTMax & 4 & 61.08 & 2.73 \\
H_Activ+TMax & & & \\
Sierra Morelos Park (SMP) & & 70.11 & 0.00 \\
TMin & 3 & 71.73 & 1.62 \\
TMax+TMin+Prec & 5 & 71.90 & 1.80 \\
TMax+TMin & 4 & 72.06 & 1.95 \\
TMin+Year & 4 & 72.81 & 2.71 \\
TMin+Prec & 4 & & \\
\hline
\end{tabular}

Explanatory variable codes: H_ activ, human activity; TMin, minimum temperature; TMax, maximum temperature; Prec, precipitation; Year, year; $\mathrm{K}$, number of model parameters. The best empirically supported model $(\triangle \mathrm{AIC}=0)$ in bold.

\section{Habitat selection}

In both sites, $C$. triseriatus were observed more frequently within the native vegetation compared to the non-native vegetation. For example, at $\mathrm{CE}, 90 \%$ of snakes were found in the grassland (index of selectivity $E_{i}=0.79$ ) and the remaining $10 \%$ in the crop fields $\left(E_{i}=-0.70\right.$, Fig. 3A). Similarly, at SMP, $82.7 \%$ of snakes were found in native (grassland) habitat $\left(E_{i}=0.10\right)$ and $17.3 \%$ in the mixed forest $\left(E_{i}=-0.11, \mathrm{Fig}\right.$. 3B). The index of selectivity indicated that snakes selected native habitat and avoided anthropized habitat at the CE; at SMP snakes showed a qualitatively similar pattern, selecting native habitat and avoiding anthropized habitat (Fig. 3). 
Table 2. Parameter estimates from the zero-inflated Poisson general linear models (GLM) of effect of human activity (CE) and minimum temperature (SMP) on C. triseriatus detectability.

\begin{tabular}{lcccc}
\hline Parameter types/names & Estimate & SE & $\boldsymbol{z}$ value & P value \\
\hline El Cerrillo (CE) & & & & \\
Intercept & 0.61 & 0.26 & 2.34 & 0.019 \\
H_activ2 & -2.75 & 1.03 & -2.6 & 0.007 \\
Sierra Morelos Park (SMP) & & & & \\
Intercept & & & & \\
TMin & 0.30 & 0.07 & -0.09 & $<0.001$ \\
\hline
\end{tabular}

H_activ2, high human activity; TMin, minimum temperature; $\mathrm{SE}$, Standard error.

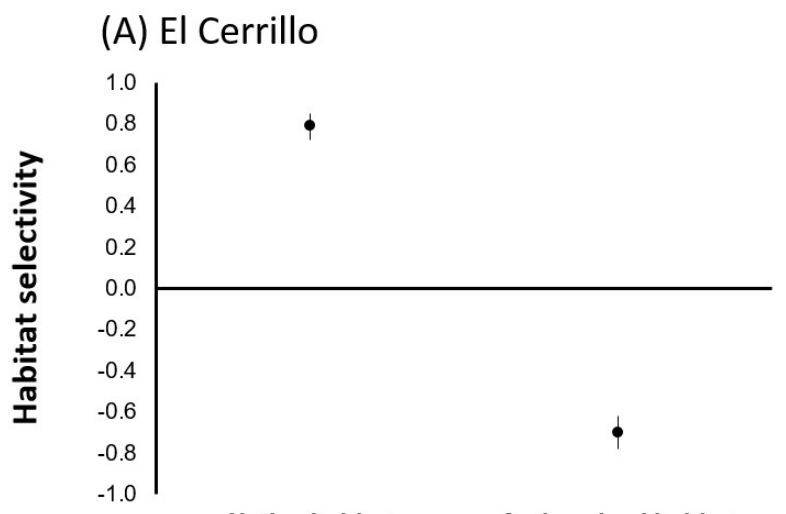

\section{(B) Sierra Morelos Park}

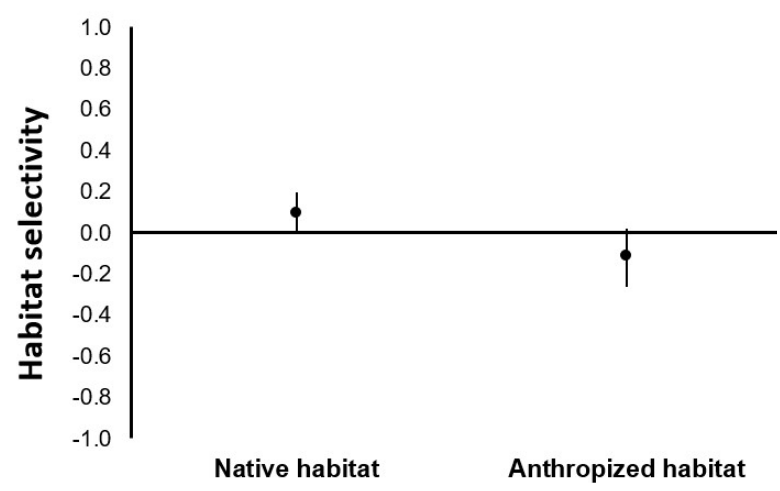

Figure 3. Index of selectivity and confidence intervals (C. I.), of C. triseriatus, in native and anthropized habitats at: (A) El Cerrillo (CE; high anthropization); native habitat $E_{i}=0.79$ (C. I. $0.72-0.85$ ), non-native habitat $E_{i}=-0.70$ (C. I-0.78,-0.62), and (B) Sierra Morelos Park (SMP; low anthropization); native habitat $E_{i}=0.1$ (C. I. 0.01, 0.20), non-native habitat $E_{i}=-0.11$ (C. I. $-0.26,0.02$ ). Values close to 1.0 indicate habitat preference, and values close to -1.0 indicate habitat avoidance.

\section{DISCUSSION}

This study shows that detectability of rattlesnakes in differently anthropized landscapes is associated with different factors. For instance, at $\mathrm{CE}$, human activity was significantly related with $C$. triseriatus detectability (Table 1 ; $A_{I} C_{c}=58.35$ ) whilst at SMP minimum temperature explained the $C$. triseriatus detectability (Table 1; $\mathrm{AIC}_{\mathrm{c}}=58.35$ ). Also, at $\mathrm{CE}$, the detectability of rattlesnakes showed two peaks, one on August and another in November, whilst at SMP, rattlesnakes presented only one peak in September (Fig. 2). Previous studies show that factors derived from anthropization in conjunction with biotic and abiotic factors, influence the activity and hence, detectability of snakes (Moore, 1978; Moreno-Rueda \& Pleguezuelos, 2007; BlouinDemers \& Weatherhead, 2002; Rocha et al., 2014; Torello-Viera et al., 2012; Weaver, 2008; Wong \& Candolin, 2015). According to our results, these factors may be interacting in different ways in the landscapes resulting from anthropic activities and affecting differently the snake populations and maybe other species populations.

Our results indicate that at $C E$, dynamics of agricultural activities affect the detectability of $C$. triseriatus, producing two monthly peaks. In agricultural areas, the preparation of the soil before sowing starts in February and runs through May, a period that coincided with zero captures of snakes. Later, the presence of snakes increased, coinciding with low agricultural activity during the growth of the crop plants (June - August). Snake captures declined again in September, this coincides with the harvest period. Detectability of $C$. triseriatus increased again with the decline in agricultural activity after maize harvest from October through January (slope estimate = -2.75+1.03; Table 2; Fig. 2).

At SMP we found that minimum temperature is related with the monthly detectability pattern of $C$. triseriatus (slope estimate $=0.30+0.07$; Table 2). At SMP, detectability of snakes began to increase in the months of high temperature (April-June). On the other hand in the colder months (December - March), there was a drastic decline in snake detectability, and thus no specimens of C. triseriatus were captured at SMP (Fig. 2B), suggesting an inactive period or possible overwinter season at this site, as it has been documented for Thamnophis scalaris (Mundo-Hernández et al., 2017). At CE, snakes' detectability also declined in the colder months; nonetheless, we detected some individuals. The effect of temperature is congruent with previous reports for the species and other rattlesnakes in temperate forests (Heimes, 2016), and is considered a central limiting factor in squamate reptiles in general, as it has been shown that they are particularly dependent on the thermal quality of the environment for thermoregulation (Gibbons \& Semlitsch, 1987; Lillywhite, 1987; BlouinDemers \& Weatherhead, 2002; Moreno-Rueda \& Pleguezuelos, 2007). These results indicate that the snakes at SMP present the same pattern of activity than other wild populations in temperate forests. Otherwise, at $\mathrm{CE}$, the detectability suggests that snakes may be changing its behaviour in response to human activity intensity; ZeroInflated Poisson GLMs confirm the above (Table 1; AICc= 58.35).

Concerning habitat selection, $C$. triseriatus also showed differences between sites. At $C E$, the habitat use index shows a strong preference for native habitat 
(grassland) and a strong avoidance for anthropized habitats. At SMP native and non-native habitats are used almost according to their availability, we detected a slight avoidance of non-native habitat. Grassland areas are considered an important habitat for this species; the intricate features of the grassland offer foraging opportunities (Matamoros-Trejo \& Cervantes, 1992; Mociño-Deloya et al., 2014; Rojas-Martínez et al., 2012) and thermal protection against low temperatures, access to solar energy for thermoregulation, and shelter from predators or humans (Campbell \& Lamar, 2004; CortesÁvila \& Toledo, 2013; Fernández-Badillo et al., 2011). The strong avoidance of anthropized habitat at $\mathrm{CE}$, indicates that agricultural activities may represent a significant negative effect on this species, this is evidenced by the low number of presence records in this habitat even when it represents most of the area $(87.3 \%)$. The low availability of native habitat may inhibit movement of snakes in the landscape (Parent \& Weatherhead, 2000), leading to a reduction in movement of individuals between populations, and potentially promoting inbreeding. In a genetic study carried out with $C$. triseriatus at Toluca Valley, the gene flow was estimated as moderate but with the possibility of decreasing if the anthropization effects continues to increase (Sunny et al., 2015). Our results also indicate that native vegetation availability is crucial for these snake's persistence as it seems that this habitat may be acting as refugees in the agricultural landscapes. This is evidenced by the great number of presence records on this habitat even when it represents a small portion of the area (12.7\%). Based on this information it seems that conservation studies and future efforts to protect rattlesnakes in anthropized landscapes should consider native habitat management and preservation.

At SMP, C. triseriatus used the anthropized and native habitats according to their availability (Fig. 3). However, snakes slightly avoided the use of anthropized habitat. The non-native vegetation presents a high tree cover ( $>75$ $\%)$, and the temperature under the canopy of trees may be inadequate for thermoregulation (Lillywhite, 1987). It has been shown that the substrate temperature, more than air temperature, is a determining factor in habitat selection by other species of viperids as Crotalus viridis, C. durissus, and Bothrops jararaca (Gannon \& Secoy, 1985; Gomes \& Almeida-Santos, 2012). Otherwise, the population at SMP is increasingly confined because there are urban settlements at the periphery of the park. If the park is not properly managed, or if the habitat is altered such that it restricts movement of snakes into and out of the site, problems of inbreeding could potentially occur. Given the limited information about $C$. triseriatus ecology in anthropized sites, the characterisation of its detectability and habitat selection may be crucial for developing effective strategies for control and management of this species. In this study, it is shown that areas with high levels of anthropization (CE) influenced the detectability and habitat selection of $C$. triseriatus. Also, in sites with lower anthropization (SMP), the climatic variables had effects on the detectability of $C$. triseriatus with a slight selection for the native habitat.
Our study shows that $C$. triseriatus presents differences in detectability and habitat selection in anthropized landscapes. Climatic conditions and human activity may be amongst the determinant factors affecting these snakes, and may be other animals, that persist around highly anthropized environments as the urban areas. Nonetheless it is necessary to identify how local differences in the anthropization process (e. g. crop management, landscape structure and composition, human density, and activity intensity) may impact in the response of species. Another important factor to consider is local climate, in this study we used data from the nearest climatic stations to the study locations; nonetheless temperature and humidity may vary at the specific location. Such information may allow for a more precise interpretation of the role of climatic conditions on snake detectability. Also, the influence of intrinsic characteristics of the individuals (e. g. sex and age), must be considered to understand possible variations in the effect of athropization in $C$. triseriatus. Finally, the aversive hunting at both places may affect population size and hence, detectability. We did not recorded any dead snake at our study sites, may be due to access restriction at $\mathrm{CE}$ and the conservation status of SMP; nonetheless, we are aware that this is a common practice in the area that need to be studied.

\section{ACKNOWLEDGEMENTS}

We want to thank the following: the 'Comisión Estatal de Parques Naturales y de la Fauna (CEPANAF)' allowed access to SMP; the organization 'IDEA WILD' supported our study with scientific and field equipment for the development of the project; and to Gabriel Varon who contributed to the fieldwork.

\section{REFERENCES}

Beaupre, S. J. (1995). Effects of geographically variable thermal environment on bioenergetics of mottled rock rattlesnakes. Ecology 76, 1655-1665.

Brown, W. S. \& Parker, W. S. (1976). A ventral scale clipping system for permanently marking snakes (Reptilia, Serpentes). Journal of Herpetology 10, 247-249.

Brown, W. S., Pyle, D. W., Greene, K. R. \& Friedlaender, J. B. (1982). Movements and temperature relationships of timber rattlesnakes (Crotalus horridus) in northeastern new york. Journal of Herpetology 16, 151-161.

Bryson, R. W., Linkem, C. W., Dorcas, M. E., Lathop, A., Jones, J. M., Alvarado-Díaz, J., Grunwald, C. I. \& Murphy, R. W. (2014). Multilocus species delimitation in the Crotalus triseriatus species group (serpentes: Viperidae: Crotalinae), with the description of two new species. Zootaxa 3826, 475-496.

Burnham, K. P. \& Anderson, D. R. (2002). Model Selection and Multimodel Inference: A Practical Information-Theoretic Approach. Springer Science \& Business Media, New York. $488 \mathrm{p}$

Campbell, J. A. \& Lamar, W. W. (2004). The Venomous Reptiles of the Western Hemisphere. Ithaca Comstock Publishing Associates, New York. 774 p.

Canseco-Márquez, L. \& Mendoza-Quijano, F. (2007). Crotalus 
triseriatus. The IUCN Red List of Threatened Species 2007: e.T64338A12771768. Available: http://dx.doi.org/10.2305/ IUCN.UK.2007.RLTS.T64338A12771768.en [Accessed: 30 August 2018].

CLICOM. (2015). Clima Computarizado. Base de datos. Available: http://clicom-mex.cicese.mx [Accessed: 30 August 2018].

COESPO. (2020). Zonas Metropolitanas del Estado de México. [versión electrónica] México. Available: https://coespo. edomex.gob.mx/zonas_metropolitanas [Accessed: 18 July 2020].

Cortes-Ávila, L. \& Toledo, J. J. (2013). Estudio de la diversidad de serpientes en áreas de bosque perturbado y pastizal en San Vicente del Caguán (Caquetá), Colombia. Actualidades Biológicas 35, 185-197.

Domínguez-Guerrero, S. F. \& Fernández-Badillo, L. (2016). Crotalus triseriatus (Mexican Dusky Rattlesnake) Diet. Herpetological Review 47, 144-145.

Fernández-Badillo, L., Morales-Capellán, N. \& MayerGoyenechea, I. G. (2011). Serpientes Venenosas del Estado de Hidalgo. México: Universidad Autónoma del Estado de Hidalgo, México. $98 \mathrm{p}$.

Filippi, E. \& Luiselli, L. (2000). Status of the italian snake fauna and assessment of conservation threats. Biological Conservation 93, 219-225.

Flores-Villela, O. \& Hernández-García, E. (1989). New state records from northern Guerrero, Mexico. Herpetological Review 20, 15-16.

Foster MS. 2012. Standard techniques for inventory and monitoring. In McDiarmid RW, Foster MS, Guyer C, Whitfield $\mathrm{G}$ and Chernoff N (eds). Reptile Biodiversity: Standard Methods for Inventory and Monitoring. Los Angeles/ California: Unversity California Press, P. 205-272.

Gannon, V. P. J. \& Secoy, D. M. (1985). Seasonal and daily activity patterns in a canadian population of the prairie rattlesnake, Crotalus viridus viridis. Canadian Journal of Zoology 63, 8691.

García, E. (2004). Modificaciones al sistema de clasificación climática de Köppen. México: Instituto de Geografía, Universidad Nacional Autónoma de México. 98 p.

Gentilli, A. (2004). Italian reptile conservation. Italian Journal of Zoology 71, 17-19.

Gibbons, J. \& Semlitsch, R. (1987). Activity patterns. Pp. 184209. In: Snakes: Ecology and Evolutionary Biology. Editors, Seigel AR, Collins TJ, Susan NS. New York, McGraw-Hill.

Glen, A. S., Byrom, A. E., Pech, R. P., Cruz, J., Schwab, A., Sweetapple, P. J., Yockney, I., Nugent, G., Coleman, M. \& Whitford, J. (2012). Ecology of brushtail possums in a New Zealand dryland ecosystem. New Zealand Journal of Ecology 36, 29-37.

Gloor, S., Bontadina, F., Hegglin, D., Deplazes, P. \& Breitenmoser, U. (2001). The rise of urban fox populations in Switzerland. Mammalian Biology 66, 155-164.

Gomes, C., Almeida-Santos, S. (2012). Microhabitat use by species of the genera Bothrops and Crotalus (viperidae) in semi-extensive captivity. Journal of Venomous Animals and Toxins 18, 393-398.

Gregory, P. T. (1982). Reptilian hibernation. In Biology of the Reptilia, Gans, C. \& Pough F. H. Eds. New York Academic Press.

Guisan, A., Edwards, T. C. \& Hastie, T. (2002). Generalized linear and generalized additive models in studies of species distributions: setting the scene. Ecological Modelling 157, 89-10.

Güizado-Rodríguez, M. A., Duifhuis-Rivera, C., Maceda-Cruz, R. J., Solano-Zavaleta, I., García-Vázquez, U. O. (2016). Notes on the diet of the Mexican Dusky Rattlesnake, Crotalus triseriatus (Viperidae). Mesoamerican Herpetology 3, 743746.

Heimes, P. (2016). Snakes of Mexico. Edition Chimaira, Germany. $572 \mathrm{p}$.

Huey, R. B., Peterson, C. R., Arnold, S. J. \& Porter, W. P. (1989). Hot rocks and not-so-hot rocks: Retreat-site selection by garter snakes and its thermal consequences. Ecology 70, 931-944.

INEGI. (2011). Censo de Población y Vivienda 2010, México. Available: www.beta.inegi.org.mx/proyectos/ccpv/2010/ [Accessed: 30 August 2018].

Jackman, S. (2020). Political Science Computational Laboratory. R package versión 1.5.5. https://cran.r-project.org/web/ packages/pscl/pscl.pdf. Accessed 27 April 2020

Krebs, J. C. (1999). Ecological methodology. The University of California, California. $620 \mathrm{p}$.

Lillywhite, H. B. (1987). Temperature, energetics and physiological ecology. Pp. 422-477. In: Snakes: Ecology and Evolutionary Biology. Editors, Seige RA, Collins JT, Novak SS. New York, McGraw-Hill.

López-Alcaide, S. \& Macip-Ríos, R. (2011). Effects of climate change in amphibians and reptiles. In Biodiversity Loss in a Changing Planet, Grillo, O. \& Venora, G. Eds. London, IntechOpen.

Madsen, T. \& Shine, R. (1996). Seasonal migration of predators and prey a study of pythons and rats in tropical Australia. Ecology 77, 149-156.

Manjarrez, J. (2017). Limitación térmica de la actividad en algunos anuros y reptiles como una estrategia ecológica (una revisión). Ciencia ergo-sum 71, 78-81.

Marzluff, J. M. \& Ewing, K. (2001). Restoration of fragmented landscapes for the conservation of birds: A general framework and specific recommendations for urbaniing landscapes. Restoration Ecology 9, 280-292.

Martins, M. \& Oliveira, M. E. (1998). Natural history of snakes in forests of the Manaus region, Central Amazonia, Brazil. Herpetological Natural History 6, 78-150.

Matamoros-Trejo, G. J. \& Cervantes, F. A. (1992). Alimentos de los roedores Microtus mexicanus, Reithrodontomys megalotis y Peromyscus maniculatus del ex lago de Texcoco, méxico. Anales del Instituto de Biología (Serie Zoología) 63, 135-144.

Mazerolle, M. J. (2019). AlCcmodavg: Model selection and multimodel inference based on (Q)AIC(c). $R$ package version 2.2-2. https :// cran.r-proje ct.org/packa ge=AlCcmodavg. Accessed 27 April 2020

Mcdonnell, M. J. \& Hahs, A. K. (2015). Adaptation and adaptedness of organisms to urban environments. Annual Review of Ecology Evolution and Systematics 46, 261-280.

Mitchell, J. C., Jung, R. E. \& Bartholomew, B. (2008). Urban Herpetology. Society for the study of Amphibians and Reptiles, Utah. 608 p.

Mociño-Deloya, E., Setser, K. \& Pérez-Ramos, E. (2014). Observations on the diet of Crotalus triseriatus (mexican dusky rattlesnake). Revista Mexicana de Biodiversidad 85, 1289-1291. 
Moore, R. G. (1978). Seasonal and daily activity patterns and thermoregulation in the southwestern speckled rattlesnake (Crotalus mitchelli pyrrhus) and the colorado desert sidewinder (Crotalus cerastes laterorepens). Copeia 1978, 439-442.

Moreno-Rueda, G. \& Pleguezuelos, J. M. (2007). Long-term and short-term effects of temperature on snake detectability in the wild: a case study with Malpolon monspessulanus. Herpetological Journal 17, 204-207.

Mundo-Hernández, V., Domínguez-Vega, H., Gómez-Ortiz, Y., Rubio-Blanco, T., Soria-Díaz, L. \& Manjarrez J. (2017). Hibernation refuge of Thamnophis scalaris (COPE, 1861), in central Mexico. Herpetozoa 29, 198-200.

Parent, C. \& Weatherhead, P. J. (2000). Behavioral and life history responses of eastern massasauga rattlesnakes (Sistrurus catenatus catenatus) to human disturbance. Oecologia 125, 170-178.

Parpinelli, L. \& Marques, O. A. V. (2008). Seasonal and daily activity in the pale-headed blindsnake Liotyphlops beui (serpentes: Anomalepidae) in southeastern brazil. South American Journal of Herpetology 3, 207-212.

Pattishall, A. \& Cundall, D. (2009). Habitat use by synurbic watersnakes (Nerodia sipedon). Herpetologica 65, 183-198.

Plummer, M. V. (2002). Observations on hibernacula and overwintering ecology of Eastern Hog-nosed snakes (Heterodon platirhinos). Herpetological Review 33, 89-89.

Prange, S., Gehrt, S. D. \& Wiggers, E. P. (2003). Demographic factors contributing to high raccoon densities in urban landscapes. Journal of Wildlife Management 67, 324-333.

R Core Team (2020) R: A language and environment for statistical computing. R Foundation for Statistical Computing, UK. https :// www.R-proje ct.org/.. Accessed 27 April 2020

Rocha, M. C., Hartmann, P. A., Winck, G. R. \& Cechin, S. Z. (2014). Seasonal, daily activity, and habitat use by three sympatric pit vipers (Serpentes, Viperidae) from southern Brazil. Anais da Academia Brasileira de Ciências 86, 695706.
Rojas-Martínez, A., Aguilar-López, M., Sánchez-Hernández, C. \& Noguera-Cobos, O. (2012). Uso del espacio y dinámica poblacional del ratón de los volcanes (Neotomodon alstoni) en el Cerro del Ajusco, Distrito Federal, México. In Estudios sobre la Biología de Roedores Silvestres Mexicanos, Cervantes, F. \& Ballesteros-Barrera, C. Eds. México, Universidad Nacional Autónoma de México.

Sullivan, B. K., Leavitt, D. J. \& Sullivan, K. O. (2017). Snake communities on the urban fringe in the sonoran desert: Influences on species richness and abundance. Urban Ecosystems 20, 199-206.

Sunny, A., Monroy-Vilchis, O., Zarco-González, M., MendozaMartínez, G. \& Martínez-Gómez, D. (2015). Genetic diversity and genetic structure of an endemic mexican dusky rattlesnake (Crotalus triseriatus) in a highly modified agricultural landscape: Implications for conservation. Genetica 143, 705-716.

Torello-Viera, N. F., Araújo, D. P. \& Braz, H. B. (2012). Annual and daily activity patterns of the snail-eating snake Dipsas bucephala (serpentes, dipsadidae) in southeastern brazil. South American Journal of Herpetology 7, 252-258.

Weaver, R. E. (2008). Distribution, abundance, and habitat associations of the night snake (Hypsiglena torquata) in washington state. Northwestern Naturalist 89, 164-170.

Wong, B. B. M. \& Candolin, U. (2015). Behavioral responses to changing environments. Behavioral Ecology 26: 665-673.

Zar, J. H. (1999). Biostatistical Analysis. Prentice-Hall, New Jersey. $663 \mathrm{p}$.

Zuur, A. F., leno, E. N., Walker, N. J., Saveliev, A. A. \& Smith, G. M. (2009). Zerotruncated and zero-inflated models for count data. In: Zuur, A. F., leno, E. N., Walker, N. J., Saveliev, A. A. \& Smith, G. M. (eds) Mixed Effects Models and Extensions in Ecology with R. Springer, New York, pp 261-293

Accepted: 2 January 2021 